\title{
O PARADOXO DA LIBERDADE EM SANTO AGOSTINHO E O ESTATUTO ONTOLÓGICO DA VONTADE FRENTE À PRESCIÊNCIA DIVINA
}

The paradox of freedom in St. Augustine and the ontological status of the will forward to the

Divine Foreknowledge

Matheus Jeske Vahl *

Resumo: Santo Agostinho é um dos primeiros autores a apresentar uma reflexão filosófica mais sistematizada sobre a liberdade. A mesma se insere no contexto da resolução de diversos problemas, oriundos do choque cultural entre a filosofia greco-romana da antiguidade tardia e o cristianismo, o mais evidente diz respeito à compatibilidade do mal e do pecado na ordem dos seres criados por um Deus sumamente bom e onisciente. Um conceito chave é o de vontade, cunhado em De Libero Arbítrio e desenvolvido também em obras posteriores. A vontade livre consiste no modo próprio de ser do homem na ordem dos seres criados, o pecado não a altera substancialmente, mas acidentalmente, a partir de seu próprio movimento voluntário. O mesmo é previsto por Deus que é presciente, o que na visão do autor não só não interfere no desenvolvimento da liberdade, como por sua Graça, consuma a efetivação dela.

Palavras-chave: Condição humana; vontade livre e presciência.

\begin{abstract}
St. Augustine is one of the first authors to present a more systematic philosophical reflection about freedom. This is in the context of the resolution of many problems arising in the cultural clash between the Greco-Roman philosophy of late antiquity and Christianity, the most obvious concerns the compatibility of evil and sin in order of beings created by a supremely good God and omniscient. A key concept is that of will, coined in De Libero Arbítrio and also developed in later works. Free will is the proper way to be the man in the order of created beings, sin does not substantially alter it, but accidentally, from its own voluntary movement. The same is planned by God that is prescient, which in the view of the author not only does not interfere in the development of freedom, for his grace, consume its effectiveness.

Keywords: Human Condition; free will and foreknowledge.
\end{abstract}

* Doutorando em Filosofia pela Pontifícia Universidade Católica do Rio Grande do Sul

\begin{tabular}{|c|c|l|l|l|l|}
\hline intuitio & $\begin{array}{c}\text { ISSN } \\
1983-4012\end{array}$ & Porto Alegre & Vol.8 $-\mathrm{N}^{\mathrm{o}} .1$ & $\begin{array}{c}\text { Junho } \\
2015\end{array}$ & p.32-45 \\
\hline
\end{tabular}


O paradoxo da liberdade em Santo Agostinho e o estatuto ontológico da vontade frente à presciência divina

\section{Introdução}

Santo Agostinho foi um dos primeiros autores a aprofundar de maneira mais sistemática a liberdade humana. $\mathrm{O}$ estatuto que oferece ao tema da liberdade, não é encontrado em nenhum outro autor contemporâneo a ele na antiguidade tardia. Contudo, vale ressaltar que suas elucidações sobre conceitos como livre arbítrio, vontade e presciência, já se encontravam em germe em algumas elaborações do pensamento patrístico desde os primeiros séculos do cristianismo ${ }^{1}$. O conceito de vontade no pensamento de Agostinho ganha destaque a partir da obra De Libero Arbítrio (397), quando o autor vê-se na eminência de resolver a discussão em torno do problema do mal na realidade humana, conciliando este com pressupostos da fé cristã, dentre os quais: a fé em um Deus sumamente bom e perfeito, bem como com a ideia de uma natureza humana criada boa por este mesmo Deus. As reflexões da obra supracitada ocorrem em um momento em que ainda fervilham, tanto na vida pessoal de Agostinho como em seu contexto histórico, as posições de orientação maniqueísta ${ }^{2}$, as quais concebiam o mal como uma força metafísica tão poderosa e atuante na realidade quanto o bem. O maniqueísmo dava um estatuto ontológico para o mal, que era incompatível com a revelação da fé cristã na visão de Agostinho.

Além disso, ele precisa conciliar o livre exercício da vontade humana e a realidade do mal cometido pelo homem, com a concepção de um Deus onisciente e bom que possui a presciência dos atos humanos, inclusive do pecado, mas que os permite. Este "conflito" entre a liberdade humana e a presciência divina será debatido, sobretudo, no terceiro livro de De libero arbítrio e terá desdobramentos em obras posteriores, assim como o conceito de vontade. Especialmente as obras da última fase de seu pensamento, especialmente as que competem ao período de embate com o pelagianismo, trarão elaborações bastante ricas sobre os problemas suscitados por De Libero Arbítrio. Nesta obra a análise do autor tende a uma defesa do primado da liberdade na ação humana que se realiza mediante a vontade livre. Para alguns comentadores como Lamberigts ${ }^{3}$ esta posição muda quando Agostinho trata do tema da Graça e da "predestinação" no período de embate com os pelagianos, o qual ocorre nos anos que competem às últimas décadas de sua vida entre 410 e 430. Contudo, autores como Gilson ${ }^{4}$, Horn $^{5}$ e Paula Oliveira ${ }^{6}$,

\footnotetext{
${ }^{1}$ Sobre este ponto ver ainda: MORESCHINI, C. História da filosofia patrística. Trad. Orlando Soares Moreira. São Paulo: Loyola, 2008.

${ }^{2} \mathrm{O}$ maniqueísmo era uma doutrina de cunho filosófico e religioso bastante difundida no Império romano tardio, sobretudo, no Norte da África onde viveu e estudou Santo Agostinho. Provém das doutrinas do profeta Mani, que em síntese tratam de conceber a realidade humana governada por duas forças, bem e mal, distintas, opostas, de igual poder e em permanente conflito. Sobre este tema ver: COSTA, Marcos R. Nunes. Maniqueísmo: história, filosofia e religião. Petrópolis: Vozes, 2003.

${ }^{3}$ LAMBERIGTS, M. Predestinación. In: FRITZGERARD, Allan (org.). Diccionario San Agustín: San Agustín a través del tiempo. Burgos, Monte Castello, 2001.

${ }^{4}$ GILSON, Etienne. Introdução ao pensamento de Santo Agostinho. 2. ed. Trad. Cristiane Negreiros Ayoub. São Paulo: Paulus, 2010.
}

\begin{tabular}{|c|c|c|c|c|c|}
\hline intuitio & $\begin{array}{c}\text { ISSN } \\
1983-4012\end{array}$ & Porto Alegre & Vol. $8-\mathrm{N}^{\circ} .1$ & $\begin{array}{c}\text { Junho } \\
2015\end{array}$ & p.32-45 \\
\hline
\end{tabular}


O paradoxo da liberdade em Santo Agostinho e o estatuto ontológico da vontade frente à presciência divina

concebem que há apenas uma mudança de enfoque na concepção apresentada em De libero arbítrio. Em virtude do contexto, as obras posteriores apenas apresentariam um enfoque mais teológico ainda ausente em seus primeiros escritos, mas a estrutura fundamental do seu pensamento permaneceria a mesma, a de uma conciliação entre o exercício da liberdade na ordem criada e a onisciência de Deus.

É importante ressaltar que dentre tantas distinções que se apresentam em nível de conteúdo entre a filosofia antiga e o pensamento medieval, ao falarmos de presciência e liberdade uma delas ganha maior destaque, o conceito de pecado, o qual traz consigo uma fundamentação antropológica distinta em muitos pontos do pensamento antigo. O mesmo decorre da forma como o pensamento cristão, cada vez mais hegemônico na antiguidade tardia, passa a conceber os princípios pelos quais deve se fundamentar o pensamento sobre o real. Segundo Montagna, com o cristianismo,

a partir dos escritos paulinos, não temos mais os males humanos como decorrência da vingança dos deuses, mas os males do mundo como decorrentes do mal ou pecado humano [...]. O pecado é então, o mal que se lança do interior do homem não permitindo que o bem prevaleça e somente é conhecido por ser refletido nas relações com as coisas [...]. Por ser interior, revela-se somente nas ações morais exteriores e reveste-se de coletividade ${ }^{7}$.

Santo Agostinho segue esta esteira do pensamento cristão que perpassa toda a patrística. Apresenta um indivíduo que não é passivo, mas ativo na realização da ordem do universo, responsável por ela ao ponto de suas ações terem o poder de desencadear o que ele definirá como "tendência ao nada", isto é, o esvaziamento do ser doado na criação. Com isto, o eixo da reflexão ética é deslocado da sedimentação da polis para a interioridade do indivíduo, cuja formação da identidade passa a ter um estatuto ontológico determinante na ordem do Ser. Por isso, a relação direta entre a "consciência individual do homem pecador" e a onipotência do Deus que governa e cuida do mundo, passa a ser determinante para Agostinho.

\section{O estatuto ontológico da vontade e a condição humana como possibilidade de ser}

Como vimos, o conceito de vontade livre perpassa quase toda obra de Santo Agostinho, constituindo-se como um de seus mais importantes legados deixados para a história da Filosofia. Sua principal formulação encontra-se em De Libero Arbítrio. O conceito de vontade já aparecera de forma

${ }_{6}^{5}$ HORN. C. Agostinho: conhecimento, linguagem e ética. Trad. Roberto H. Pich. Porto Alegre: EDIPUC, 2008.

${ }^{6}$ OLIVEIRA e SILVA. Paula. Ordem e mediação: a ontologia relacional de Agostinho de Hipona. Porto Alegre: Letra e Vida, 2012.

${ }^{7}$ MONTAGNA, L. A. A ética como elemento de harmonia social em Santo Agostinho. 2. ed. Sarandi: Humanitas Vivens, 2009, p. 68.

\begin{tabular}{|c|c|c|c|c|c|}
\hline intuitio & $\begin{array}{c}\text { ISSN } \\
1983-4012\end{array}$ & Porto Alegre & Vol. $8-\mathrm{N}^{\circ} .1$ & $\begin{array}{c}\text { Junho } \\
2015\end{array}$ & p.32-45 \\
\hline
\end{tabular}


menos veemente em outros autores da antiguidade, entre os quais destacamos São Paulo, mais precisamente o capítulo 7 de sua Carta aos Romanos, onde ele apresenta certa ideia de vontade, cujos traços serão amplamente retomados por Agostinho. Diz o Apóstolo:

Sabemos, de fato, que a Lei é espiritual, mas eu sou carnal, vendido ao pecado. Não entendo absolutamente o que faço, pois não faço o que quero; faço o que não quero. E, se faço o que não quero, reconheço que a Lei de Deus (lei natural), é boa. Mas, então, não sou eu que o faço, mas o pecado que em mim habita. Eu sei que em mim, isto é, na minha carne não habita o bem, porque o querer o bem está em mim, mas não sou capaz de efetuá-lo. Não faço o bem que quereria, mas o mal que não quero $(\operatorname{Rm} 7,14-20)$.

Aprofundando esta problemática psicológica e ao mesmo tempo ética colocada por Paulo, Agostinho entende que a vontade é a força motriz pela qual o homem estabelece suas relações com seu "em torno". Trata-se da faculdade da alma que primariamente é a responsável pelo agir humano. Buscando dissociar a vontade criada do pecado, Agostinho responde em debate com seu amigo Evódio: "é preciso contar a vontade livre entre os bens, e não dos menores, portanto, precisamente reconhecer a vontade como dom de Deus" ${ }^{\prime}$. No entanto, há de se reconhecer que na origem do pecado encontra-se o movimento da vontade humana que se volta para as coisas sensíveis e corpóreas dando a elas valor acima das coisas espirituais, originando o que o autor intitula "mala voluntas", a qual consiste em uma disposição de ser do homem em direção às coisas sensíveis, tomadas como fim em si mesmas e não mais reconhecidas na totalidade do sentido da ordem ${ }^{9}$. Desde este momento, a alma humana, antes criada para a Beatitude, passa a caracterizar-se pelo "conflito", os desejos originariamente voltados para a contemplação da Verdade revelada na ordem do real, agora "dão testemunho de uma vontade dividida contra si mesma por causa dos desejos que fazem a alma voltar-se a diversas direções"10. Tratam-se de movimentos diversos de uma e mesma vontade em direção a fins diversos, não significam a presente de “duas vontades” na alma do indivíduo, mas a "má condição"de uma faculdade vital perante a realidade.

\footnotetext{
${ }^{8}$ AGOSTINHO. O livre arbítrio. 3. ed. Trad. Nair de Assis Oliveira. São Paulo: Paulus, 2008, p. 147.

9 Este conceito de ordem é fundamental para entender a problemática aqui apresentada, Agostinho o expõe pormenorizadamente em De Ordine, diálogo da primeira fase de seu pensamento (386). Em síntese, Agostinho concebe que toda a criação foi criada dentro de uma certa ordem disposta por Deus, na qual o homem possui uma condição ontológica diferenciada em virtude de ser dotado de vontade e razão. Portanto, ele é o único capaz de compreender o sentido da ordem e de ser co-participante desta criação, uma vez que pode compreender sua totalidade. Do ponto de vista filosófico, o pecado consiste exatamente na perversão desta condição, pois, na medida em que o homem toma os bens sensíveis como valores em si, sem concebê-los em relação a Deus e ao restante da criação, ele já não a compreende em sua totalidade e, por conseguinte, não efetiva seu télos que é conduzi-la à Beatitude. Sobre este tema ler ainda: OLIVEIRA e SILVA. Paula. Ordem e mediação: a ontologia relacional de Agostinho de Hipona. Porto Alegre: Letra e Vida, 2012.

${ }^{10}$ DJUTH, M. Voluntad. In: FRITZGERAD, Allan (org.). Diccionario San Agustín: San Agustín a través del tiempo. Burgos, Monte Castello, 2001. p. 1340.
}

\begin{tabular}{|c|c|c|c|c|c|}
\hline intuitio & $\begin{array}{c}\text { ISSN } \\
1983-4012\end{array}$ & Porto Alegre & Vol.8 $-\mathrm{N}^{\mathrm{o}} .1$ & $\begin{array}{c}\text { Junho } \\
2015\end{array}$ & p.32-45 \\
\hline
\end{tabular}


O paradoxo da liberdade em Santo Agostinho e o estatuto ontológico da vontade frente à presciência divina

Em um primeiro momento poder-se-ia crer que a vontade humana possui certa inclinação natural ${ }^{11}$ para o sensível, o que acarretaria em admitir que desde sua criação a vontade já se encontraria comprometida ao pecado. Isto implicaria também em dizer, que o mal se encontra atrelado ao âmbito da necessidade o que não conferiria ao homem culpa alguma. Tal posição fere o que para o autor é um valor inviolável na ordem da criação - a liberdade humana. Agostinho nega com veemência esta postura, afirma que "se não hesitamos em declarar culpável este movimento na alma, é preciso que neguemos absolutamente que ele é natural”, ${ }^{12}$, e ao mesmo tempo admitir que

nada pode sujeitar o espírito à paixão, porque nem um agente superior, nem inferior pode constrangê-la a esse vexame, visto que seria uma injustiça. Tampouco, um agente inferior possui poder para tal. Resta, portanto, que seja próprio da vontade aquele movimento pelo qual ela se afasta do Criador e se dirige às criaturas (...), ele não é natural, mas voluntário ${ }^{13}$.

Na visão de Santo Agostinho, todas as coisas foram criadas boas por Deus e dispostas em certa ordem para a Beatitude, inclusive a natureza humana e a vontade que a ela pertence. O mal não está atrelado à ordem da causalidade das coisas, não possui substancialidade, consiste meramente em um acidente que decorre do livre movimento da vontade humana, por isso, não afeta substancialmente nem a ela, nem ao restante da natureza criada, sua conseqüência é apenas acidental, decorrendo tão somente do mau uso do livre-arbítrio. O problema não está, portanto, na condição natural da faculdade anímica em si, mas em algo que a transcende, a liberdade, trata-se de certo "poder" contido na alma que a permite operar com a vontade para fins que não lhe são próprios.

Quanto ao homem, chamado, por criação, natural, a ocupar lugar entre os anjos e os seres irracionais, Deus [...] criou-o, porém, de tal forma, que se sujeito a seu Criador [...], lhe cumprisse piedosa e obedientemente os preceitos, passaria sem morrer, na companhia dos anjos, a gozar de imortalidade feliz e eterna, mas se pelo contrário, usando com soberba e desobedientemente o livre-arbítrio, ofendesse o Senhor seu Deus, seria sujeito a morte e viveria bestialmente, escravizado pela libido [...]. Não fê-lo para privá-lo da sociedade humana, e sim para encarecer-lhe sempre mais unidade social e vínculo de concórdia ${ }^{14}$

Na mesma obra ele diz ainda: "quando a vontade, abandonando o que é superior, converte-se às coisas inferiores, torna-se má, não por ser mau o objeto a que se converte, mas por ser má a própria conversão [...], ela que é sua própria causa, por ter apetecido mal o ser inferior" ${ }^{\text {15 }}$. O pecado não se trata,

\footnotetext{
${ }^{11}$ Sobre esta questão Agostinho irá admitir mais adiante a existência de uma inclinação do homem ao pecado, contudo, não a partir de sua natureza, mas da concupsciência, proveniente do pecado original que irá se configurar como uma "segunda natureza" no homem.

${ }^{12}$ AGOSTINHO. O livre arbitrio. 3. ed. Trad. Nair de Assis Oliveira. São Paulo: Paulus, 2008, p. 147.

${ }^{13}$ AGOSTINHO. O livre arbítrio. 3. ed. Trad. Nair de Assis Oliveira. São Paulo: Paulus, 2008, p. 150.

${ }^{14}$ AGOSTINHO. A Cidade de Deus. Trad. Oscar Paes Leme. Petrópolis: Vozes, 2012, v.2, p. 110.

${ }^{15}$ AGOSTINHO. A Cidade de Deus. Trad. Oscar Paes Leme. Petrópolis: Vozes, 2012, v.2, p. 83.
}

\begin{tabular}{|c|c|c|c|c|c|}
\hline intuitio & $\begin{array}{c}\text { ISSN } \\
1983-4012\end{array}$ & Porto Alegre & Vol. $8-\mathrm{N}^{\circ} .1$ & $\begin{array}{c}\text { Junho } \\
2015\end{array}$ & p.32-45 \\
\hline
\end{tabular}


O paradoxo da liberdade em Santo Agostinho e o estatuto ontológico da vontade frente à presciência divina

portanto, de uma necessidade naturalmente operada pela vontade como se esta estivesse atrelada a uma cadeia causal dos fatos, mas de um ato livremente consentido pelo homem. O movimento da vontade em direção às coisas sensíveis é uma possibilidade inerente em sua criação, mas a qual o homem não deveria ter consentido de modo a cumprir seu sentido na ordem do universo.

Este movimento livre da vontade ao aproximar-se das coisas inferiores, atraída pela sedução ${ }^{16}$ que elas operam no espírito humano, tem como conseqüência o afastamento de Deus e a cegueira dos olhos humanos, donde se segue a perda da liberdade originária. Tendo sido criada à imagem e semelhança de Deus,

a alma, deleitando-se com seu próprio poder, resvala do bem universal ao seu bem particular. A culpa é do orgulho que ama as divisões. [...]. Com efeito, se a alma seguisse a Deus governador da criatura, suas leis divinas poderiam governá-la com sabedoria. Mas ela, desejando algo mais do que o universo, quis submeter o mundo a suas leis particulares. E, assim, ao ambicionar muito, diminui-se ${ }^{17}$.

Em última análise, o pecado consiste em uma degradação da natureza humana criada boa por Deus, trata-se de um movimento em que a alma, antes destinada à plenitude do Ser na Beatitude, agora toma a direção do nada, do não ser, do afastamento do sentido. Dependendo da forma como o homem ama as coisas, a vontade o aproxima ou afasta do sentido do Ser, cuja fonte é Deus criador. Em virtude da liberdade, o homem é visto por Agostinho como radical possibilidade, tanto ao Ser, quanto ao nada. Segundo Mendonça e Barbosa, aqui

a antropologia agostiniana vai ao ponto de sustentar que um simples ato praticado - aqui e agora - pode colaborar para a reposição daquilo que a queda originária desbotou, mas pode também servir para desordenar mais o que já está desordenado (...). Este é o risco da liberdade ${ }^{18}$.

Isto leva Santo Agostinho a conceber que o "sábio" não está determinado previamente à Beatitude $^{19}$, a excelência da alma virtuosa trata-se de uma permanente construção do homem ao longo de

${ }^{16}$ Sobre este tema vale ressaltar a seguinte passagem das "Confissões" em que Agostinho disserta sobre o movimento do pecado em sua própria alma dizendo: "Quando se indaga a razão por que se praticou um crime, esta ordinariamente não é digna de crédito, se não descobre que a sua causa por ter sido ou o desejo de alcançar alguns dos bens ínfimos, ou o medo de os perder. Esses são sem dúvida belos e atraentes" (Conf. II, 5,11). O Santo Doutor volta a comentar este tema em Comentário ao Livro do Gênesis contra os Maniqueus II, 14 ao falar da tentação da serpente e dos afetos.

${ }^{17}$ AgOSTINHO. A Trindade. 4. ed. Trad. Frei Augustino Belmonte. São Paulo: Paulus, 2008, p. 379.

${ }^{18}$ MENDONÇA, M. ; MORAES BARBOSA, D. É possível conciliar presciência divina e liberdade humana: a resposta de Agostinho no De Libero Arbítrio. Revista Civitas Agostiniana. Porto, v.1, no 1, p. 59-78, 2012, p. 69.

${ }^{19}$ Há que se atentar para uma certa "evolução" deste tema nas obras de Agostinho. Se nos primeiros escritos como Solilóquios e De Beata Vita ele mantém ainda grande influência do pensamento grego, concebendo que a Sabedoria se conquista por uma purificação intelectual da alma mediante o conhecimento das realidades eternas, em escritos posteriores ele muda radicalmente, sobretudo, após De Libero Arbitrio. Para Agostinho o cristianismo é a grande "Sabedoria" dada à humanidade, somente por ele o homem pode encontrar a Beatitude, o que exige para além de

\begin{tabular}{|c|c|l|l|l|l|}
\hline intuitio & $\begin{array}{c}\text { ISSN } \\
1983-4012\end{array}$ & Porto Alegre & Vol. $8-\mathrm{N}^{\circ} .1$ & $\begin{array}{c}\text { Junho } \\
2015\end{array}$ & p.32-45 \\
\hline
\end{tabular}


O paradoxo da liberdade em Santo Agostinho e o estatuto ontológico da vontade frente à presciência divina

sua história, na qual não há uma condição definitiva. Este é um ponto em que o pensamento cristão difere bastante do que comumente se concebia na filosofia antiga; por ser essencialmente livre, a natureza humana nunca se encontra definitivamente determinada, ao contrário, ela está em constante construção de si mesma. Cada decisão tomada pelo homem dotado de vontade, "aqui e agora", traz em si toda sua existência, passada e futura, que neste mesmo ato é colocada sempre diante do Deus presente acima de todo o universo, mas especialmente presente na intimidade da consciência humana. Isto significa que em cada ato existencialmente praticado, o homem decide toda sua existência e presta conta desta decisão ao seu Criador.

É esta faculdade que confere ao homem a sua dimensão essencial de "ser em aberto". Contrariamente aos animais, todo homem está constituído na forma de empreendimento. As diversas situações em que se encontra o existir, longe de lhe serem meros preenchimentos exógenos, são possibilidades de execução de $\mathrm{si}^{20}$.

Por isso para Agostinho o pecado consiste numa degradação do ser, pois, na medida em que aprisiona a vontade nas coisas meramente sensíveis, tornando-a vontade culpável, compromete seu ser e tolhe sua liberdade frente à ordem criada. Exatamente por ser racional e livre, que o homem pode exercer a função para a qual foi criado, de "zelador" da ordem, conforme indica o livro do Gênesis, o que se efetiva pelo fato de o homem ter sido criado como o "ser relacional" por excelência.

Justamente a unidade das relações essenciais que o ser humano com o restante da realidade, sustentada no diálogo, à semelhança do "Ser trinitário"21, que foi tolhida pela vontade culpável, ao dividir a alma tornando os seres sensíveis fins em si mesmos. Tomando o real dessa forma, o homem deixa também de contemplá-lo em relação a um Deus trinitário, cuja forma de ser torna-se estranha a ele. A degradação de ser de que fala Agostinho em De Libero Arbítrio, efetiva-se exatamente quando o homem cessa de realizar-se no mundo, mediante a abertura de sua razão e vontade, como imagem de Deus, ou seja, como ser essencialmente livre que realiza a unidade mediante uma relação dialógica de amor com os seres múltiplos, cuja unidade fundamental é o Ser por excelência que os criou.

O grande paradoxo que toma conta da obra agostiniana, é que mesmo sabendo que com a vontade livre o homem poderia e haveria de pecar, Deus assume o referido risco e o cria com ela, até mesmo porque como fica claro nos últimos escritos do autor, somente por ela o homem pode realizar o

uma "purificação intelectual" uma atitude e purificação existencial, onde mais do que a atividade racional, o ato de fé ganha um peso significativo.

${ }^{20}$ MENDONÇA, M. ; MORAES BARBOSA, D. É possível conciliar presciência divina e liberdade humana: a resposta de Agostinho no De Libero Arbítrio. Revista Civitas Agostiniana. Porto, v.1, nº1, p. 59-78, 2012, p. 65.

${ }^{21}$ Sobre a elaboração da teoria da Trindade e a forma como Agostinho apresenta sua visão do mundo a partir da mesma, ler ainda sua obra: "A Trindade" e o comentário: OLIVEIRA e SILVA. Paula. Ordem e mediação: a ontologia relacional de Agostinho de Hipona. Porto Alegre: Letra e Vida, 2012.

\begin{tabular}{|c|c|l|l|l|l|}
\hline intuitio & $\begin{array}{c}\text { ISSN } \\
1983-4012\end{array}$ & Porto Alegre & Vol.8 $-\mathrm{N}^{\circ} .1$ & $\begin{array}{c}\text { Junho } \\
2015\end{array}$ & p.32-45 \\
\hline
\end{tabular}


O paradoxo da liberdade em Santo Agostinho e o estatuto ontológico da vontade frente à presciência divina

desígnio de consolidar a unidade e a concórdia entre os seres criados. Aos que refutam que assim o Criador não haveria de tê-lo então criado, Agostinho responde que "cessem suas lamentações, pois, além de Deus ter manifestado toda sua bondade no ato criação, manifestou também sua justiça punindo-o e, sobretudo, sua grande misericórdia salvando-o"22. Dessa forma, podemos afirmar com Agostinho que se Deus tivesse impedido o homem de exercer sua livre vontade no ato mesmo do pecado, ou ainda criado este sob outra condição pela qual não poderia cometer pecado algum, teria Deus comprometido a condição do homem que deixaria de ser "humano", acabando por ser definitivamente rebaixado na ordem dos seres na criação ${ }^{23}$.

Segundo Santo Agostinho o homem é co-criador da criação, à qual foi dado o ser para que se desenvolva no tempo. Nesse sentido, ele afirma: "não denominamos os pais criadores de homens e nem dizemos que os agricultores são criadores dos frutos da terra, embora Deus atue interiormente, utilizandose dos movimentos humanos exteriores para criar essas $\operatorname{coisas}^{24}$, tal participação no Ser o homem só pode realizar no exercício mesmo de sua liberdade, por isso, na visão de Agostinho não há nada mais contraditório com a revelação da ordem criada, do que entender o homem fora desta condição, ou pior, do que entendê-la como um mal na natureza humana. O desafio se torna mais complexo para Agostinho, entender como Deus integra, na ordem dos seres criada boa por Ele, a degradação do próprio ser desta mesma criação.

\section{A liberdade como "modo de ser" próprio do homem e sua relação com a Presciência Divina: o "aparecimento da misericórdia"}

Agostinho afirma ${ }^{25}$ que se Deus tem a presciência das ações pecaminosas do homem, tanto mais o possui de suas ações salvíficas para conosco, as quais nada mais almejam do que restaurar a condição humana frente à ordem criada, a qual mesmo manchada pelo pecado não é comprometida em sua natureza, como afirma o hiponense, "Ele estabeleceu, uma vez por todas, como deve decorrer a ordem do universo que criou, e nada o dispõe a novo querer" ${ }^{26}$. Quando se refere à ordem, o autor não fala de um determinismo causal estabelecido por Deus no ato da criação, no qual poderia estar incluído inclusive o pecado, a ação de Deus não está atrelada a temporalidade, Ele transcende o próprio tempo que é ser criado por Ele. Nesse sentido, que a ontologia agostiniana opera com "modos de ser" próprios de cada ser criado,

${ }^{22}$ AGOSTINHO. O livre arbítrio. 3. ed. Trad. Nair de Assis Oliveira. São Paulo: Paulus, 2008, p. 152.

${ }^{23}$ AGOSTINHO. O livre arbítrio. 3. ed. Trad. Nair de Assis Oliveira. São Paulo: Paulus, 2008, p. 81.

${ }^{24}$ AGOSTINHO. A Trindade. 4. ed. Trad. Frei Augustino Belmonte. São Paulo: Paulus, 2008, p. 125.

${ }^{25}$ AGOSTINHO. O livre arbitrio. 3. ed. Trad. Nair de Assis Oliveira. São Paulo: Paulus, 2008, p. 155.

${ }^{26}$ AGOSTINHO. O livre arbítrio. 3. ed. Trad. Nair de Assis Oliveira. São Paulo: Paulus, 2008, p. 156.

\begin{tabular}{|c|c|l|l|l|l|}
\hline intuitio & $\begin{array}{c}\text { ISSN } \\
1983-4012\end{array}$ & Porto Alegre & Vol.8 $-\mathrm{N}^{\circ} .1$ & $\begin{array}{c}\text { Junho } \\
2015\end{array}$ & p.32-45 \\
\hline
\end{tabular}


os quais se desenvolvem no tempo, onde ao homem foi conferido ser racional e livre. Segundo Ayoub, na criação

o que existiria estava na matéria informe como semente, conquanto ainda não existissem atualizadas todas as características do que as criaturas se tornariam no futuro (...). Aquilo que é e ainda não foi constituído como uma criatura determinada já é uma criatura indeterminada (...), o ser e a vida não são iluminados efetivamente, mas o são por antecipação na medida em que correspondem a capacidade de serem iluminados ${ }^{27}$.

Na ordem da criação o homem é o único ser dotado de vontade livre, ou seja, não condicionado a agir pela necessidade natural, seu "ser" que será ontologicamente desenvolvido no tempo é essencialmente liberdade, por isso, afirma Agostinho "nada se encontra tão plenamente em nosso poder do que a própria vontade" 28 , ou seja, "cada homem tem à sua disposição, de modo imediato e inequívoco, o poder de opostos, e suas escolhas não são indiferentes para assunção ou não de sua própria forma"29. O que ocorre no pecado é uma renúncia voluntária do homem que passa a agir por uma vontade culpável, a qual o condiciona à ordem das coisas sensíveis, tolindo seu ser livre na ordem da criação. Com base nisto, podemos dizer que o pecado nos infiltra em um paradoxo, "pela nossa própria vontade livre perdemos a liberdade" 30 .

Ainda assim, segundo Agostinho, mesmo admitindo que Deus preveja as nossas vontades e ações futuras, "não se segue que não queiramos algo sem vontade livre (...), a vontade culpável ainda que esteja em nós, não deixará de ser vontade livre pelo fato de Deus ter previsto a sua existência futura"31. Este é um ponto caro para o pensamento de Agostinho, a "incorruptibilidade" da liberdade humana, nem a presciência de Deus, nem a ação da Graça, muito menos o pecado, atingem de maneira essencial ${ }^{32}$ a liberdade humana. Em outras palavras, aquilo que Deus conhece de antemão é a realidade de um movimento intencional da alma humana, chamado liberdade, que se dá pela vontade e pelo livre-arbítrio. Portanto, mesmo Deus prevendo nossas ações, auxiliando-nos pela Graça, afirma o pensador africano em De Libero Arbítrio, que

${ }^{27}$ AYOUB, C. Iluminação trinitária em Santo Agostinho. São Paulo: Paulus, 2011, p. 37.

${ }^{28}$ AGOSTINHO. O livre arbítrio. 3. ed. Trad. Nair de Assis Oliveira. São Paulo: Paulus, 2008, p. 156.

${ }^{29}$ MENDONÇA, M. ; MORAES BARBOSA, D. É possível conciliar presciência divina e liberdade humana: a resposta de Agostinho no De Libero Arbítrio. Revista Civitas Agostiniana. Porto, v.1, nº1, p. 59-78, 2012, p. 69.

${ }^{30}$ Há que se destacar uma sutil distinção que há no pensamento de Agostinho entre livre-arbítrio e liberdade. O primeiro consiste numa faculdade concebida unicamente unida à vontade, a qual dá ao homem condição de agir em direções diversas. O segundo consiste em um "estado de ser" do homem não submetido a um condicionamento externo que pode lhe ser imposto por ele mesmo como no caso do pecado. Nesta consistiria o estado originário da natureza humana sem o pecado.

${ }^{31}$ AgOSTINHO. O livre arbítrio. 3. ed. Trad. Nair de Assis Oliveira. São Paulo: Paulus, 2008, p. 157.

${ }^{32}$ Ao conceituar a vontade culpável como origem do mal enquanto "menos ser", Agostinho admite que a natureza humana é atingida em nível meramente acidental.

\begin{tabular}{|c|c|l|l|l|l|}
\hline intuitio & $\begin{array}{c}\text { ISSN } \\
1983-4012\end{array}$ & Porto Alegre & Vol.8 $-\mathrm{N}^{\mathrm{o}} .1$ & $\begin{array}{c}\text { Junho } \\
2015\end{array}$ & p.32-45 \\
\hline
\end{tabular}


O paradoxo da liberdade em Santo Agostinho e o estatuto ontológico da vontade frente à presciência divina

nós queremos livremente aquilo que queremos. Se o objeto da presciência é a nossa vontade, é essa mesma vontade que se realizará (...). A presciência não me tira este poder, que me pertencerá tanto mais seguramente, quanto mais Aquele que não se engana previu que me pertenceria ${ }^{33}$.

O ponto crucial da discussão está em não se tomar a presciência atrelando diretamente o ponto de vista epistêmico ao lógico e, em seguida, ao ontológico. Primeiramente é preciso distinguir que se Deus "conhece" nossas ações no tempo, não necessariamente o faz mediante as categorias lógicas com que pensamos, estas estão atreladas a nossa forma de pensar, que não necessariamente corresponde à razão divina, a qual só temos acesso por um espelho daquilo que nos é revelado. Além disso, o conhecer não significa necessariamente atrelar-se ao agir, por isso, segundo Mendonça e Barbosa,

o cerne do dilema não está na presciência divina, mas sim na presciência enquanto tal (...). Trata-se aqui de vincar uma distinção entre dois domínios, o domínio do conhecimento ou epistemológico, e, por outro lado, o domínio da realidade ou ontológico. Este opera com noções de ser e não ser. Aquele tem em vista o verdadeiro e o falso, sempre que ambos se confundem ocorrem falácias (...). Segundo Agostinho a presciência dos acontecimentos é alheia à determinação da necessidade destes acontecimentos. Aquilo que Deus conhece é a realidade de um movimento do espírito (...), é a própria vontade de cada homem, em cada momento em que se configura existencialmente desta ou daquela forma ${ }^{34}$.

Logo, a presciência não consiste em uma arbitrariedade de Deus frente à liberdade, ao contrário, prevendo o pecado humano, Deus age de modo a salvar o homem da degradação de seu ser pela vontade culpável, prevê os que hão de pecar por sua própria vontade, embora não seja co-autor de seu pecado, não atua na vontade livre a não ser mediante a Graça, contudo, mesmo através desta, mantém preservada a liberdade humana. Aí está um domínio caro ao pensamento agostiniano, a ação de Deus por excelência sobre a vontade humana é a misericórdia, mediante a qual se atua tendo em vista a restauração e não a condenação do gênero humano. Trata-se de um domínio que escapa ao âmbito epistêmico da razão por estar fixado ontologicamente em sua própria criação. Na visão de Agostinho,

a criação é res gesta por excelência e em sentido primordial, porque o mundo começou quando foi feito por Deus a partir do nada e porque, a partir desse acontecimento primordial, todas as criaturas são o que são. A criação é um acontecimento único que decorre exclusivamente da vontade divina (...). Nada é real como o ato criador, e ele não é comparável a qualquer ato das criaturas. Assim, embora o homem busque se referir a tal ato, as palavras e os conceitos tomados da experiência humana são inadequadamente aplicados a Deus ${ }^{35}$.

A liberdade de Deus em relação ao exercício da liberdade humana, não pode ser aprendido logicamente, pois não pertence ao domínio epistêmico da razão enquanto tal, se assim o fosse possível, a

\footnotetext{
${ }^{33}$ AGOSTINHO. O livre arbítrio. 3. ed. Trad. Nair de Assis Oliveira. São Paulo: Paulus, 2008, p. 159.

${ }^{34}$ MENDONÇA, M. ; MORAES BARBOSA, D. É possível conciliar presciência divina e liberdade humana: a resposta de Agostinho no De Libero Arbítrio. Revista Civitas Agostiniana. Porto, v.1, nº 1, p. 59-78, 2012, p. 73-74.

${ }^{35}$ AYOUB, C. Iluminação trinitária em Santo Agostinho. São Paulo: Paulus, 2011, p. 53.
}

\begin{tabular}{|c|c|c|c|c|c|}
\hline intuitio & $\begin{array}{c}\text { ISSN } \\
1983-4012\end{array}$ & Porto Alegre & Vol. $8-\mathrm{N}^{\circ} .1$ & $\begin{array}{c}\text { Junho } \\
2015\end{array}$ & p.32-45 \\
\hline
\end{tabular}


O paradoxo da liberdade em Santo Agostinho e o estatuto ontológico da vontade frente à presciência divina

razão humana poderia colocar-se para além do tempo e interrogar seu próprio ato de ser, contudo, isso significaria negar sua própria existência. Ao homem resta, no entanto, não calar frente à diferença ontológica com relação a Deus, mas alçá-lo sob uma racionalidade mais profunda, a contemplação da ordem dos seres, em que o Ser como doador de sentido se manifesta ${ }^{36}$. Retomando o texto paulino supracitado, Agostinho comenta a passagem do Apóstolo, demonstrando que não há contradição entre a ação de Deus e a liberdade humana, ao contrário, quando o Criador age pela Graça tem como fim justamente confirmar e purificar o exercício daquela condição em que o homem foi criado, frente à ação do pecado na história. Assim diz Agostinho:

Há de se evitar que alguém pense que estas palavras do Apóstolo (faço o mal que não quero e não faço o bem que quero), façam desaparecer o livre arbítrio da vontade. O que o Apóstolo descreve é o homem sob a lei colocado diante da Graça. Então, o venciam os pecados quando ele pretendia viver por suas próprias forças, sem a ajuda da Graça libertadora. No exercício do livre arbítrio o homem tem que crer no Libertador e Dele receber a Graça, a fim de que não peque mais, libertando-se, deste modo, do jugo da lei do pecado, através do cumprimento da Lei da caridade de Deus [...]. Se existirem, como descreve o Apóstolo os desejos que me levam ao pecado, mas eu não os obedecer, então, não somos, de fato, cativos, já vivemos a caridade. Contudo, a concupsciência da carne ${ }^{37}$ solicita continuamente a nossa vontade ${ }^{38}$.

O que Agostinho expõe seguindo Paulo, é que a condição humana após a queda não é uma condição de plena liberdade, mas de "conflito". Deus, no entanto, não é indiferente a este conflito, atua na história mediante a Graça que vem auxiliar o homem a reconstituir sua vontade, cujo exercício da liberdade o conduz a realizar o sentido ontológico mais profundo de seu ser, que é garantir a unidade entre a multiplicidade dos seres criados. No entanto, Deus opera esta segunda forma de agir na criação, que a Tradição cristã denomina salvação, sem prescindir da liberdade humana, ao contrário, é por ela que sua ação se efetiva . Segundo Agostinho,

Embora saiba pela presciência os que Nele crêem, Deus dá aos que querem e crêem, a faculdade de agir bem mediante o Espírito Santo, por quem a caridade de Deus se difunde em nossos corações. Sem dúvida isto é verdade, mas entendendo-se antes que o agir bem é de Deus porque prepara nossa vontade, mas também é nosso porque Deus não o leva a cabo sem o nosso querer ${ }^{39}$.

\footnotetext{
${ }^{36}$ Trata-se aqui da via da interioridade pela qual segundo o bispo de Hipona podemos transcender o âmbito das coisas sensíveis e contemplar, pela razão e pela fé, as verdades eternas que se manifestam na ordem. Para aprofundar este conceito, faz-se mister consultar: De Trinitate XII; Confissões X e XI e OLIVEIRA e SILVA, 2012.

${ }^{37}$ Faz-se mister esclarecer que os termos derivados de "carne" e "espírito", tanto no texto paulino, quanto no agostiniano possuem um significado mais amplo que dizem respeito ao âmbito interno da moralidade que se realiza na alma. Para ambos, "a antítese entre o espírito e a carne é uma distinção moral e não uma distinção metafísica. Agostinho afirma um conflito moral radical dentro do ser humano, não um choque entre substâncias independentes". Cf: DUFFY, S. Antropología. In: FRITZGERAD (org.), 2001, p. 92. - N. A.

${ }^{38}$ AGUSTÍN, San. Exposición de la Epístola a los Romanos. In: Obras completas de San Agustín. Madrid: La Editorial Católica/BAC, 1983a, vol. XVIII, p. 43.

${ }^{39}$ AGUSTIN, San. Retractaciones apud Exposición de la Epístola a los Romanos. In: Obras completas de San
}

\begin{tabular}{|c|c|l|l|l|l|}
\hline intuitio & $\begin{array}{c}\text { ISSN } \\
1983-4012\end{array}$ & Porto Alegre & Vol.8 $-\mathrm{N}^{\mathrm{o}} .1$ & $\begin{array}{c}\text { Junho } \\
2015\end{array}$ & p.32-45 \\
\hline
\end{tabular}


O paradoxo da liberdade em Santo Agostinho e o estatuto ontológico da vontade frente à presciência divina

A Graça é, portanto, dom de Deus que se faz próximo do homem na luta contra o pecado e, ao mesmo tempo, é permanente "conquista" do homem no exercício de sua liberdade, ou seja, a presciência não torna o homem passível diante da atuação da Graça. Deus age para salvar o homem, mas não determina sua salvação de antemão, ela passa, pois, pela participação da vontade humana no transcurso de sua história. $\mathrm{O}$ homem participa da reconstituição de sua vontade na medida em que transforma suas relações com seu mundo em torno, mediante um processo ascético pelo qual ele aprende a amar as coisas de outra forma. Na realidade criada, inclusive corporal, ao buscar a unidade e a edificação da concórdia ${ }^{40}$, que a natureza verdadeira do homem se revela como livre e participante da essência divina.

Poderíamos nos perguntar então, junto com os interlocutores contemporâneos a Agostinho: não poderia Deus ter criado o homem de tal modo que este quisesse apenas louvar-lhe e render-lhes graças por todos os séculos, sem jamais aceitar o pecado? Ou mesmo que ele escolhesse de uma vez por todas a Sabedoria que conduz à Felicidade em Deus e uma vez escolhida, dela não se apartasse? Agostinho responde:

Que cessem esses lamentos e não censurem ao Criador! Pois criando-os assim, Deus não os forçou a pecar, visto que lhes deu o poder de o cometer ou não, caso o quisessem (...). $\mathrm{Na}$ verdade se te comprazes com uma criatura cuja vontade persevera até o fim sem pecar, certamente tens razão de a preferir àquela que peca (...), a criatura pecadora possui o lugar que lhe compete pelo princípio da ordem. Ela perdeu a bem-aventurança pecando, mas não pode perder a possibilidade de a recuperar. Tudo se realiza de tal forma que sempre fica intacta a vontade-livre do pecador (...). Uma criatura que peca por sua vontade livre, é melhor do que aquela outra que é incapaz de pecar por carecer desta mesma vontade livre ${ }^{41}$.

Mediante a presciência, Deus não evita que o homem peque, muito menos o contrário, causa-lhe o pecado de alguma forma. Ao prever a ação humana no exercício de sua liberdade, Deus realiza seu plano de salvação do homem. Desta feita, podemos então concluir que em Agostinho há dois valores intocáveis e plenamente conciliáveis, a bondade do Criador e sua mais plena manifestação na ordem da criação - a condição humana dotada de razão, vontade e corporeidade. Podemos afirmar com Agostinho que a liberdade é o traço mais característico e distintivo do ser humano. Doado por Deus ele não é tolido em momento algum, exceto no pecado cometido pelo próprio homem, assim mesmo apenas de maneira acidental. Mesmo prevendo esta chaga em sua mais amada criatura, o Criador em momento algum o destitui da condição em que foi criado, ao contrário, prevenindo o pecado pela justiça que lhe é própria, salvando o homem em sua própria história, Ele quer restaurá-la, sempre mantendo sua integridade.

Agustín. Madrid: La Editorial Católica/BAC, 1983b, vol. XVIII, p. 10.

40 Sobre este tema através do qual Agostinho debate com o pensamento vários autores da antiguidade tardia, sobretudo com Cícero, é crucial ver: De Civitate Dei XVIII e XIX.

${ }^{41}$ AGOSTINHO. O livre arbittrio. 3. ed. Trad. Nair de Assis Oliveira. São Paulo: Paulus, 2008, p. 165.

\begin{tabular}{|c|c|l|l|l|l|}
\hline intuitio & $\begin{array}{c}\text { ISSN } \\
1983-4012\end{array}$ & Porto Alegre & Vol.8 $-\mathrm{N}^{\circ} .1$ & $\begin{array}{c}\text { Junho } \\
2015\end{array}$ & p.32-45 \\
\hline
\end{tabular}




\section{Considerações finais}

Longe, portanto, de determinar a ação humana, a ação de Deus tem por fim tornar o espírito humano mais livre de todo o pecado e de toda culpa. Segundo Lettieri ${ }^{42}$ a Graça atua no espírito humano como luz que abre os olhos do homem, antes obscuros porque voltados unicamente ao sensível, para a beleza da criação e para o Sumo Bem. Trata-se, portanto, de uma ação libertadora de Deus, que consuma a liberdade da vontade humana, possível de ser realizada apenas por Aquele que é mais íntimo do homem do que ele mesmo, ou seja, por Deus, que antecipando o conhecimento da própria auto-condenação do homem, pode também antecipar sua salvação.

A presciência, assim como toda ação de Deus enquanto doador de ser e sentido não está atrelada ao âmbito da manifestação causal, querer compreendê-la a partir destas categorias é um erro, a verdade sobre o Ser transcende o transcurso do tempo, e ao homem foi dado contemplá-la em sua imagem e semelhança, contudo, isto não se dá logicamente, mas enquanto manifestação ou numa linguagem cristã, como revelação. Por isso, em Agostinho, a vontade humana precisa ser compreendida em analogia a esta mesma forma de ser, onde não cabe a fórmula lógica: "se A, então P”, o que significa dizer não uma ação humana que possa ser prevista ou pré-determinada pela operação singular da razão. Para Agostinho a liberdade humana é uma manifestação de ser que não se enquadra em regras estabelecidas previamente, por ela o homem se realiza como imagem e semelhança do Ser, este é essencialmente kairótico, ou seja, plena novidade em constante manifestação, assim deve ser entendido o exercício da vontade livre do homem, aquém de qualquer determinismo causal.

Sem dúvida uma das grandes transformações que o pensamento de Santo Agostinho legou ao Ocidente foi a maneira de pensar a realidade desde o ponto de vista dos indivíduos singulares e sua livre manifestação, contudo, a forma como estes são compreendidos toma um caráter peculiar. Para o autor o indivíduo é uma espécie de "microcosmos", cuja consciência individual reporta-se apenas a Deus, o Ser que transcende a tudo o que existe. Com isto, o problema moral é deslocado da esfera pública para a interiodade, o pecado é o mal que ocorre na intimidade do espírito humano ao qual apenas Deus, enquanto Ser acima de todos os seres pode ter acesso e agir, o que transforma a consciência individual no primeiro grande "juíz" da ação livre em detrimento de quaisquer aspectos de foro externo. Isto significa, que para Agostinho, a liberdade não se configura como um postulado comum a todos os seres humanos, mas como uma condição, um estado de cada homem, que deve ser desvelado no interior de cada consciência em sua

${ }^{42}$ LETTIERI, G. Agostino d' Ippona. Torino: San Paolo, 1999, p. 60.

\begin{tabular}{|c|c|c|c|c|c|}
\hline intuitio & $\begin{array}{c}\text { ISSN } \\
1983-4012\end{array}$ & Porto Alegre & Vol.8 $-\mathrm{N}^{\mathrm{o}} .1$ & $\begin{array}{c}\text { Junho } \\
2015\end{array}$ & p.32-45 \\
\hline
\end{tabular}


O paradoxo da liberdade em Santo Agostinho e o estatuto ontológico da vontade frente à presciência divina

relação "privilegiada" com a Verdade que é Deus. A justiça humana frente aos atos livres de cada homem será sempre imperfeita em sua visão, pois, o grande "julgamento" e, ao mesmo tempo, a ação misericordiosa de Deus, acontece no âmbito da interioridade da consciência, nunca plenamente factível para a razão comum dos homens.

\section{Referências}

AGOSTINHO, Santo. Confissões. Trad. Arnaldo do Espírito Santo. Lisboa: Imprensa Nacional-Casa da Moeda, 2000 .

. Comentário ao Gênesis. Trad. Augustino Belmonte. São Paulo: Paulus, 2005.

.O livre arbítrio. 3 ed. Trad. Nair Assis de Oliveira. São Paulo: Paulus, 2008.

. A Trindade. 4. ed. Trad. Frei Augustino Belmonte São Paulo: Paulus, 2008.

. A vida feliz. 4 ed. Trad. Adaury Fiorotti. São Paulo: Paulus, 2010.

. Solilóquios. 4 ed. Trad. Adaury Fiorotti. São Paulo: Paulus, 2010.

. A cidade de Deus. Trad. Oscar Paes Leme. Petrópolis: Vozes, 2012. v.1 e v.2.

. Exposición de la Epístola a los Romanos. In: Obras completas de San Agustín. Ed. bilingüe. Trad. José

Luiz Garcia. Madrid: La Editorial Católica/BAC, 1983, vol. XVIII.

. Retractaciones apud Exposición de la Epístola a los Romanos. In: Obras completas de San Agustín.

Madrid: Ed. bilingüe. Trad. José Luiz Garcia. Madrid: La Editorial Católica/BAC, 1983, vol. XVIII.

AYOUB, C. Iluminação trinitária em Santo Agostinho. São Paulo: Paulus, 2011.

BÍBLIA SAGRADA. Edição de Jerusalém. São Paulo: Paulus, 2008.

COSTA, Marcos Roberto Nunes. Maniqueísmo: história, filosofia e religião. Petrópolis: Vozes, 2003.

DUFFY, S. Antropología. In: FRITZGERAD, Allan (org.). Diccionario San Agustín: San Agustín a través del tiempo. Burgos, Monte Castello, 2001.

DJUTH, M. Voluntad. In: FRITZGERAD, Allan (org.). Diccionario San Agustín: San Agustín a través del tiempo.

Burgos, Monte Castello, 2001.

ERIÚGENA, S. Treatise on divine predestinacion. Notre Dame: University of Notre Dame, 2002.

FLACH, K. Introduzione alla filosofia medievale. Torino: Einaudi, 1995.

GILSON, Etienne. Introdução ao pensamento de Santo Agostinho. 2. ed. Trad. Cristiane Negreiros Ayoub. São

Paulo: Paulus, 2010.

HEIDEGGER, M. Fenomenologia da vida religiosa. Trad. Ênio Paulo Giachini. Petrópolis: Vozes, 2010.

HORN. C. Agostinho: conhecimento, linguagem e ética. Trad. Roberto H. Pich. Porto Alegre: EDIPUC, 2008

LAMBERIGTS, M. Predestinación. In: FRITZGERAD, Allan (org.). Diccionario San Agustín: San Agustín a través del tiempo. Burgos, Monte Castello, 2001.

LETTIERI, G. Agostino d' Ippona. Torino: San Paolo, 1999.

MENDONÇA, M. ; MORAES BARBOSA, D. É possível conciliar presciência divina e liberdade humana: a resposta de Agostinho no De Libero Arbítrio. Revista Civitas Agostiniana. Porto, v.1, n.1, p. 59-78, 2012.

MONTAGNA, L. A. A ética como elemento de harmonia social em Santo Agostinho. 2. ed. Sarandi: Humanitas Vivens, 2009.

MORESCHINI, C. História da filosofia patrística. Trad. Orlando Soares Moreira. São Paulo: Loyola, 2008. OLIVEIRA e SILVA. Paula. Ordem e mediação: a ontologia relacional de Agostinho de Hipona. Porto Alegre: Letra e Vida, 2012.

Recebido em: 16/05/2014

Aprovado para a publicação em: 27/04/2015

\begin{tabular}{|c|c|l|l|l|l|}
\hline intuitio & $\begin{array}{c}\text { ISSN } \\
1983-4012\end{array}$ & Porto Alegre & Vol. $8-\mathrm{N}^{\circ} .1$ & $\begin{array}{c}\text { Junho } \\
2015\end{array}$ & p.32-45 \\
\hline
\end{tabular}

